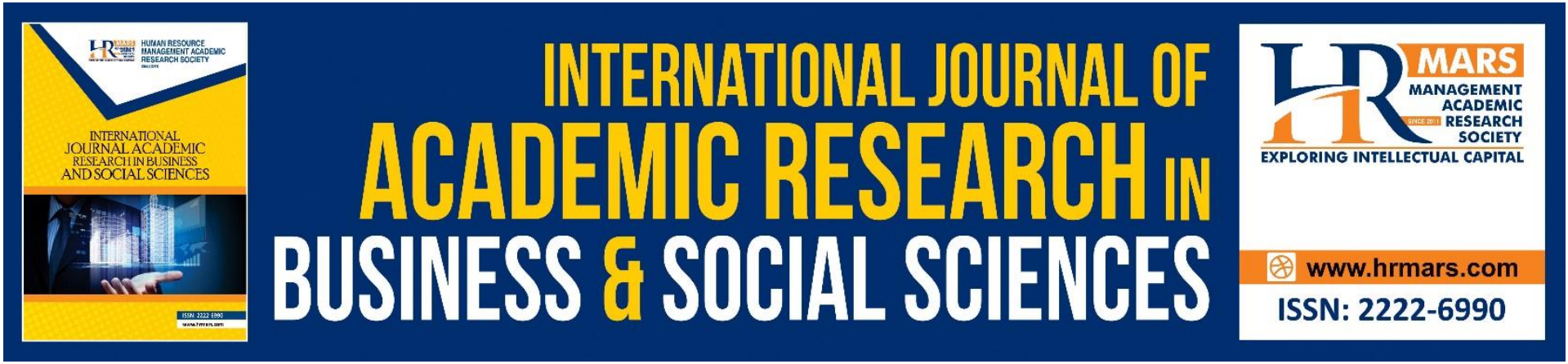

\title{
Design Thinking for Creative Teaching of Chemistry.
}

Komathy Veerasinghan, Balamuralithara Balakrishnan, Muhd Ibrahim Muhamad Damanhuri, Kumaran Gengatharan

To Link this Article: http://dx.doi.org/10.6007/IJARBSS/v11-i3/8979 DOI:10.6007/IJARBSS/v11-i3/8979

Received: 21 January 2021, Revised: 22 February 2021, Accepted: 06 March 2021

Published Online: 16 March 2021

In-Text Citation: (Veerasinghan et al., 2021)

To Cite this Article: Veerasinghan, K., Balakrishnan, B., Damanhuri, M. I. M., \& Gengatharan, K. (2021). Design Thinking for Creative Teaching of Chemistry. International Journal of Academic Research in Business and Social Sciences, 11(3), 670-687.

Copyright: (c) 2021 The Author(s)

Published by Human Resource Management Academic Research Society (www.hrmars.com)

This article is published under the Creative Commons Attribution (CC BY 4.0) license. Anyone may reproduce, distribute, translate and create derivative works of this article (for both commercial and non-commercial purposes), subject to full attribution to the original publication and authors. The full terms of this license may be seen

at: http://creativecommons.org/licences/by/4.0/legalcode

Vol. 11, No. 3, 2021, Pg. 670 - 687

Full Terms \& Conditions of access and use can be found at http://hrmars.com/index.php/pages/detail/publication-ethics 


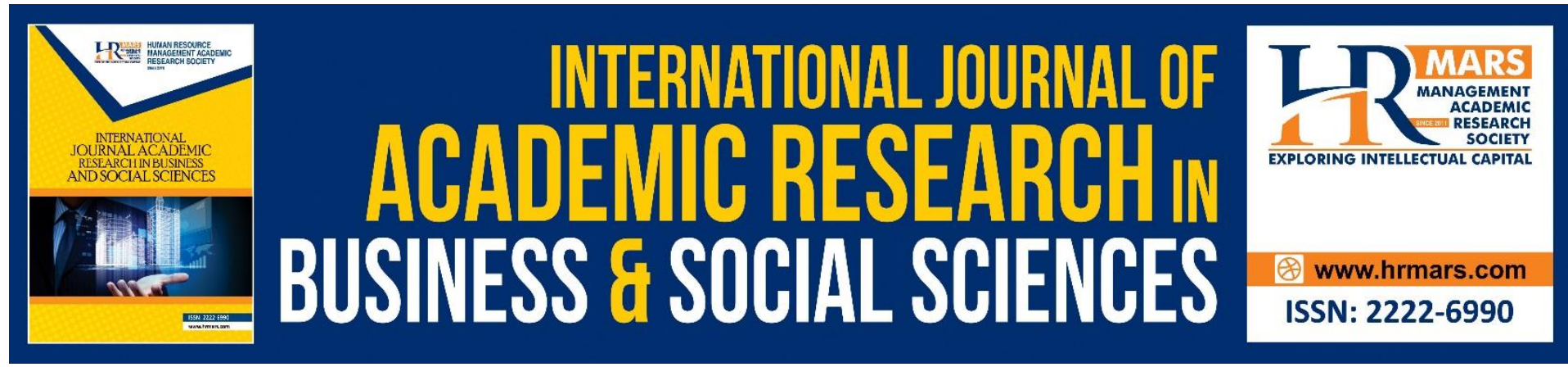

\title{
Design Thinking for Creative Teaching of Chemistry.
}

\author{
Komathy Veerasinghan ${ }^{1}$, Balamuralithara Balakrishnan ${ }^{1}$, Muhd \\ Ibrahim Muhamad Damanhuri ${ }^{1}$, Kumaran Gengatharan ${ }^{2}$ \\ ${ }^{1}$ Faculty of Science and Mathematics, Sultan Idris Education University, Malaysia, ${ }^{2}$ Faculty of \\ Sports Science and Coaching, Sultan Idris Education University, Malaysia \\ Email: komathy2112@gmail.com
}

\begin{abstract}
The current problem in chemistry education is the lack of creative teaching in a chemistry classroom. There is a lack of exploration in learning experiences that engage students in realistic, thought-provoking problems, working with others, and applying their knowledge, skills, and creativity to find solutions to real-world problems. One of the biggest challenges for Malaysian secondary chemistry education is that few guidelines or models exist regarding teaching chemistry creatively in the classroom. Therefore, this paper provided a systematic and analytical strategy in mapping out and offering a critical review on design thinking in education. Overall, this study recognized the gains that can be made from utilizing Design Thinking in education, especially in the global quest of teaching 21st-century skills, and had recommended using Design Thinking in the Lesson plan and Project-Based Learning. This paper also suggested a need to pursue further studies on developing a Design Thinking framework for creative teaching and how these could motivate and excite students and themselves in the creative teaching of chemistry in the classroom.
\end{abstract}

Keywords: Stem, Chemistry Education, Creative Teaching, Design Thinking.

\section{Introduction}

According to the Ministry of Education, Malaysia (MOE), in 2015, there were only 90 000 (18\%) students enrolled in the science stream out of the average of 500000 from four students, which is far away from the targeted $60 \%$. Therefore immediate action should be taken to overcome this problem. One of MOE's critical issues is the lack of new and attractive teaching strategies in the classroom that could create interest in STEM (Science, Technology, and Engineering \& Mathematics) education among the students (Sadler, 2013; Ali et al., 2015). It is identified that students of the current generation need fun and challenging learning processes- newness- to create interest in a specific subject. Creative and innovative teachers can bring newness in content selection, lesson plans, organize material, and create assessment - overall pedagogy- that could help students develop essential knowledge and skills on the subject matter and build attitude towards creativity (Starko, 2013). To do this in the classroom, teachers need a solid grounding in creativity and innovation. 
As mentioned above, the low level of creativity among Malaysian chemistry teachers and university chemistry student-teachers has been highlighted by the result of recent researches (DeWitt \& Alias, 2016). In this context, chemistry teaching and learning are facing challenges because of the fundamental concepts that need to be developed in teaching and learning, meanwhile, creative skills are also important to be developed. Chemistry is considered a difficult subject since its characteristic of abstract concepts and relation to students' daily lives. Chemistry subject involves three representations of macroscopic, microscopic, and symbolic representation (Treagust \& Duit, 2008). These three representations need to be discussed by chemistry teachers to develop a good understanding of chemistry concepts. In addition to these characteristics, students used to teach for passing the test by memorizing the facts and ignoring the concepts. Therefore, chemistry learning becomes difficult and less meaningful.

In short, creative teaching is teachers having creativity and showing vivid and lively teaching methods to make students interested in learning (Smith, Rama, and Helms 2018), thus enhancing the teaching effectiveness of teachers and in return foster the creativity skills among the students. The purpose of creative teaching in the classroom in the teachers' area: (1) Enhancing teaching quality and effectiveness; (2) Having rich and diverse teaching content and methods; (3) Having a diversified student assessment and; (4) Achieving educational goals and ideals. The focus of creative teaching is based on the trust that every student can learn and be successful in life. A teacher should perceive each student as possessing unique personality characteristics that can be more polished by using creative teaching methods. Having an awareness of the process of learning is very helpful for teachers to identify the problems students are facing in some of the subjects (Westwood, 2013).

In the creative performance model, Amabile (2018) highlighted that the creativity of an individual could be divided into three main components: (1) domain-relevant skills, (2) creativity-relevant skills, and (3) task motivation. In the first and second components of the creative performance model, it is mentioned that an individual needs implicit or explicit knowledge and appropriate skills for creating original ideas that can be obtained through training and also via formal and informal education (Amabile 2018). Creativity can be learned, and in the context of this investigation, exposure to the right tool to facilitate creative thinking skills among the teachers is crucial to enable them to unleash their creative skills.

Design thinking is a powerful approach that boosts creativity and launches innovation (Melles et al., 2015 \& Smith, Rama, and Helms, 2018). This powerful approach could be utilized as an important tool for teachers to create new and original teaching methods in a classroom since the teachers who teach chemistry subjects facing challenges and under pressure to design lessons that engaging and create interest in chemistry among students (Foster, 2019). Thus, the design thinking concept could be utilized to overcome the problem of infusing creative teaching of chemistry in the classroom. This process also enables every teacher to bring out the maker in every student. (Koh et al, 2015) cited that design thinking could be utilized effectively to transform teachers' pedagogical beliefs and practices. This new paradigm of pedagogy design; enables the fostering of creativity among the students. (Nelson et al., 2016) mentioned that to promote creativity, teachers must embed creative pedagogy in classrooms. With this creative pedagogy which is out of an old model of lesson design, the teaching and learning process of chemistry subjects can be more meaningful and fun that 
instill interest in chemistry subjects. Design thinking able to bring out the maker's mind in teachers.

Hence, to instill a deep interest in chemistry education among students, teachers need to be highly creative when preparing and delivering their lessons to meet the requirements and needs of students. Thus, chemistry teachers need to be exposed to a tool such as the DT framework with which they can utilize to create interesting, efficacious teaching materials and plan engaging learning activities in their chemistry classroom. The focus of the creative teaching here is to develop original and new ideas of lesson plans by the chemistry teachers using the DT framework designed. Equally important, the findings of this study, a type of study that has not been well researched, can provide greater insight into the understanding of DT as a potent tool to help teachers improve their current teaching practices for chemistry subjects.

\section{Stem Education}

In globalization, digitization, and the fourth industrial revolution, the need for talents in science, technology, engineering, and mathematics (STEM) is becoming more pronounced to move the country forward. There is a general agreement about the importance of STEM education globally, and reports cite the need for a workforce with STEM skills to drive economic prosperity and the contribution that STEM can make in solving the 'wicked' problems of the world via science and technology (World Economic Forum, 2016). STEM education in its ideal form addresses more than merely academic and economic outcomes. Personal, social, and economic development all required more than STEM knowledge and skills. There is an understanding that STEM education should develop a set of personal attributes that are variously known in the education sector as 21st-century skills, soft skills or general capabilities include problem-solving, collaboration, creativity, and innovation technology (World Economic Forum,2016). This is often associated with an inquiry-based pedagogy. STEM learning is a predominantly social imperative. STEM is necessary to solve real-world challenges, and we need people with strong STEM literacy to address the complex problems facing the world. STEM literacy is a pressing economic issue. Future national productivity demands workers able to fill STEM-related jobs to withstand global competition. Most of the world's countries face the challenge of ensuring that young people develop the level of STEM expertise required to confidently address these concerns (World Economic Forum,2018). While Australia appeared in the list of countries leading their regions in gaining STEM-related skills (World Economic Forum, 2016), there is an ongoing fear of 'brain drain' related to losing too many of the best graduates. A theme running through the STEM rhetoric is that STEM jobs are 'jobs of the future' (Andrews, 2015). The World Economic Forum (2016) counts STEM literacy as a measure of countries' future-readiness. In this context, the challenge of STEM learning is building capacity in learners to thrive in the 'known unknown' of future careers and communities.

According to the latest Organization for Economic Co-operation and Development (OECD) Education at a Glance 2017 report, Germany has attained a leading position in science, technology, engineering, and mathematics or STEM subjects. However, the report criticizes stagnation in upward mobility in the country's education system. According to education at a Glance (2017), 40\% of first-year students in Germany's tertiary sector - mainly comprising university studies and master craftsman programs - opted for STEM fields in 2015. This is significantly higher than, for example, Mexico (32\%), South Korea (31\%), the United Kingdom 
(29\%), Japan (21\%), and Turkey (18\%). The OECD average was a $27 \%$ STEM connector, professional services company, and conducted an investigation that identified the deficiencies and areas of opportunity in the teaching and Learning of Mathematics, Technology, Science, and Engineering.

In Malaysia, to equip the students with the skills needed to face the challenges of a changing global with the application of STEM, the MOE is responsible for ensuring an increase in the ratio of students who wish to pursue scientific and technical fields. In the Malaysian Education Blueprint (MEB) 2013-2025, the MOE has stated the five factors that cause the decline. The quality of student outcomes in STEM education includes (1) Lack of awareness in STEM education. (2) STEM subjects are considered problematic. (3) A reliable curriculum content. (4) Less consistent with the quality of teaching and learning. (5) Old and inadequate infrastructure. These factors or problems must be overcome so that MOE's desire in MEB 2013-2025 can be achieved.

Parallel to this, according to Ahmad et al. (2012), a total of $18 \%$ of Malaysian children have limited prerequisite knowledge and skills in science classrooms; meanwhile, $55 \%$ of them had limited prior knowledge in science. According to the Ministry of Science, Technology, and Innovation (MOSTI, 2017), only $44.9 \%$ of Malaysians are interested in new scientific discoveries. In contrast, far more Americans (87.0\%) and Europeans (78.0\%) expressed an interest in these issues, exceeding Malaysians by $42.1 \%$ and $33.1 \%$, respectively. As for the Malaysian population, this proves that more than one-third of the children clearly expressed a lack of interest in STEM. However, the interest in STEM in schools and, consecutively, universities seem to be waning as reflected in the insufficient enrolment into the science stream at secondary schools and the lack of suitable candidates for STEM-based programs at universities. National STEM Movement chairman Datuk Professor Dr. Noraini Idris said this disinterest in science and mathematics stemmed from uninspired teaching of the subjects at schools, which had a continued impact at the higher-education level (Idris, 2019).

Nevertheless, the number of students who have chosen STEM fields has continued to decline in recent years (Halim \& Meerah, 2016). Currently, only $42 \%$ of middle school students in Malaysia chose to do science, including technical and vocational programs at high school (MOE, 2016). The percentage of middle secondary school students who met the requirement to study science at upper secondary but chose not to increase to approximately $15 \%$ (MOE, 2013). The declining number of Malaysian students enrolling in the science stream is due to many reasons: (i) STEM subjects are complicated and less attractive, (ii) STEM only for good students, and (iii) STEM careers are 'less glamorous' (Jayarajah et al., 2014). These reasons are mainly contributed by the school environment in the teaching and learning process in the classroom. (Li, 2014) cited that schools are the most important place where students can be inspired, reinforced their interest in STEM, and prepare them for the STEM workforce. Thus, the integral of solving all the pertaining issues and problems related to STEM is the school. The classroom is the leading platform for students to instill interest in STEM, in which interest is the primary predictor of whether a student pursues his/her career path in STEM fields (Regan \& Dewitt, 2014). Loss of interest and negative attitude towards STEM subjects among schoolchildren will affect the future of the STEM workforce and a country's development.

Today's students are tomorrow's leaders. Occupations in STEM-related careers are some of the fastest growing and best paid of the 21st century, and they often have the most tremendous potential for job growth. Like America, Germany, Australia, and Singapore strive to keep up with the current and projected demand for STEM output. Malaysia must remain 
competitive in STEM fields, as we have mentioned so far. The best way to ensure future success and longevity is to make sure that Malaysian students are well versed in these subjects. Building a solid STEM foundation through the consistent quality of teaching and learning-creative teaching is the best way to instill interest among students in STEM, which is the primary predictor of whether a student pursues his/her career path in STEM fields (Burnard, 2016).

\section{Creativity in Stem Classroom}

To teach and learn creatively is a goal that every teacher would want in class. Some may have found their means in incorporating such values in their chemistry class. According to the Malaysian Ministry of Education (MEB, 2013-2025), some are still struggling to carry out their classes. Based on current observations (MEB, 2013-2025), the steps and pedagogical approaches that Malaysian chemistry teachers are accustomed to for decades now might impose a rigid structure to carry out what is deemed an effective classroom. Policies and law enforcement relating to STEM education reflect the current state of affairs in the country. As a matter of analysis and critically looking at the new Malaysian educational blueprint, there are a few changes to introducing and including creativity in schools. However, there is also a worrying perception of how creativity is viewed within the system so far. The Malaysian national education system is currently undergoing a transformational shift through the Malaysian Education Blueprint under the 11th Malaysian Plan that began in 2013 and is expected to be evident by 2025. Within the pages of this blueprint, it is stated in the first shift, that is to provide Malaysians with equal access for quality education of an international standard where the school curriculum at both primary and secondary levels will be revised to embed a balanced set of knowledge and skills such as creative thinking, innovation, problemsolving, and leadership (MOE, 2013).

The blueprint is also stated about the four pillars for student aspiration that encompasses knowledge, thinking skills, leadership skills, and bilingual proficiency. Among these four pillars, what is further explained within the scope of 'knowledge' includes encouraging students to develop their knowledge and STEM skills (MOE, 2013). Another explanation within the scope of 'thinking skills' included creative thinking as part of the skills every Malaysian student should master in school (MOE, 2013). How are Malaysian chemistry teachers going to teach creative thinking if it was not included in their educational teacher training at the beginning? Perhaps, the ministry ought to include changes within the teacher training institutes and the educational blueprint at large. If enhancements were made simultaneously, perhaps shortly, creativity would be more evident in classrooms throughout Malaysia.

The theories that relate to creativity in teaching are often ambiguous to the practice of creativity in classrooms. For example, using the scenarios brought forward in an article by Grainger, Barnes, and Scoffham (2004), the current focus on reading, writing, and arithmetic dominates the classroom time, and creative tasks are often perceived to be less critical. This is also happening in current Malaysian schools, where the chase for better test results outweighs the importance of introducing new methods to ensure students' joyfulness in school. This also means that no matter how strong a point is delivered by theory and introduced to chemistry teachers in their training, there is no guarantee that teachers would know how to conduct creative teaching when they begin working in a public school. 
Even though teachers will keep on questioning the national education policies' visions and goals, the show must go on. Malaysian chemistry teachers have found many ways to work around the system to emphasize values through a variety of creative methods in a class (Lee, 2020). Creative teaching is defined as using imagination in teaching approaches to make learning more exciting and effective (Ellingson, 2018). This can happen in any chemistry class of any level depending on the teacher's creativity and how he or she handles the lesson. Chemistry Lessons can match students' interests or tap into a standard memory among the class students. This is a common way of teaching chemistry subjects that all teachers can incorporate exciting games and activities into their lessons, set inductions, or get closure for the class.

When creativity exists in schools, there will be a more conducive environment for learning chemistry through joy and happiness (Starko \& Krynski, 2020). So, how does a chemistry teacher carry out creative teaching in regular classes? It is not easy to fulfill such creative tasks in the chemistry classroom, primarily when the year's academic session deals with more examination periods rather than hands-on and practical skills. Students often see memorizing facts as the best way possible to cover the entire syllabus at once and regurgitate what they have previously memorized to pass the significant ministry examination with flying colors that may or may not bring positive outcomes later in life (Thomas \& Budnik, 2017).

Many scholars argue that for students to be fully prepared for STEM careers, they should engage in pedagogical practices that reflect the interdisciplinary, ill-defined problems that scientists face (Sindia, 2015). In response, many countries have developed reforms and initiatives to shape teaching and learning across STEM disciplines. A number of these are interdisciplinary and integrative, with blurred boundaries among the four disciplines (Kidman \& Casinader, 2017).). Linking STEM subjects offers considerable advantages, notably getting students to make sense of learning content across the four subjects while promoting critical thinking and problem-solving skills (Jamil \& Khairuddin, 2017).

Educators have shown that creative teaching has been useful in getting students to make sense of learning science content within the science syllabus students study in school. This creative teaching has mainly worked well for the academically less-inclined students. Amir, Siew \& Chong (2015) argues that while the prescribed science experiments in the secondary school activity books for these students allow teachers to engage them in learning through creative teaching, a large number of these experiments provide little room to foster and reward these students for being able to showcase their creativity through knowledge from science. In doing these experiments, students are seen to be going through a routine of steps as instructed by their teachers, with hardly much opportunity for them to put their imaginative and inventive skills to fair use (Steele \& Whitaker, 2019). (Irwanto, 2018) These students have been observed to ask questions about the relevance of learning some of the skills and concepts taught in the experiment books. (Irwanto, 2018) cited an example of their observation of students asking questions on how learning the vernier caliper's skills to measure the internal and external diameter of a test tube and compact disc (as described in their activity books) would be useful for them in their daily lives. Creative teaching in a classroom could address some of these concerns motivating students to learn chemistry (Silverman, 2015). However, the choice of the way of teaching to be presented to students does matter. Ideas from educators have shown that creative teaching in the classroom that kindles interest in students does make a difference in motivating them to be interested in doing the subjects (Otte et al., 2019). However, very little research has explicitly examined on creative teaching of chemistry in the classroom. 


\section{Issues in Chemistry Education}

According to Widodo (2018), chemistry education research focused on improving learning activities in chemistry, mainly helping students understand the concepts of chemistry and creating meaningful Learning. Thus, research in chemistry education, generally focused on learning methods, to understand how learners and other aspects of learning such as curriculum and assessment (Febriana \& Arlianty, 2017). In this context, chemistry teaching and Learning face challenges because of the fundamental concepts that need to be developed in teaching and Learning. Meanwhile, these 21st-century skills are also essential to be developed.

Chemistry is considered a tricky subject since its characteristic of abstract concepts and relation to students' daily lives (Cardellini, 2012). Chemistry subject involves three representations of macroscopic, microscopic, and symbolic representation (Russell, 1997). These three representations need to be discussed by chemistry teachers to develop a good understanding of chemistry concepts. In addition to these characteristics, students used to teach for passing the test by memorizing the facts and ignoring the concepts. Therefore, chemistry learning becomes challenging and less meaningful.

The education system's ability to develop and respond to this growing need for skills is central to its integrity. It remains the center for job readiness for future generations of workers. This has led to a restructuring of educational curricula, teaching, and test-taking, though this has yet to be a unanimous process. Examples of these changes include better curricula to support abstract knowledge on subjects, teaching that focuses on problem-based learning, and testing to measure students' progression into their 21st-century skills mindset. However, teaching skills such as self-direction, collaboration, and creativity are not a straightforward or fully understood process (Odell \& Kennedy 2020). Many studies have presented a gloomy picture concerning science's learning styles, especially at the secondary school level (Hofstein \& Eilks, 2017 and Balaji, 2017). An essential claim is that science education - particularly in chemistry - remains unpopular among students. Several of these studies (Ingram, 2020; Diaz et al., 2018 and Nieswandt \& Horowitz, 2015) infer that students are insufficiently interested in chemistry and/or not motivated to learn chemistry concepts and topics. Learners were frequently found to perceive chemistry as "irrelevant" both for themselves and for the society in which they live. Science teachers in general, and chemistry teachers in particular, are urged to make learning science (chemistry in our case) "more relevant" to motivate their students better and interest them in learning chemistry (Hofstein \& Kesner, 2006).

According to Touli et al (2015), in the teaching of science in general and chemistry, the primary mission is to help students understand the natural world and its phenomena from a scientific approach. When it comes to understanding a particular process in chemistry, this can be done by scientific experiments in the laboratory. However, to understand a particular theory or concept, more hands-on activities are encouraged to develop the ideas in the student's mind.

A teacher will change the students' mindset by exploring different methods and teaching styles in chemistry class. Many teachers have researched the mole concept, atomic structure, thermodynamics, electrochemistry, covalent bonding, ionic bonding, and gases for some decades (Niaz \& Luiggi, 2014; Yaman, Ayas \& Çalik, 2019; Fulmer, 2013). These researches did not explore the creative teaching in chemistry. Educators assert that 
knowledge is enhanced when students are actively engaged in the learning process. When this is coupled with guidance and scaffolding from the instructor, students can better understand science concepts (Muhlisin, 2017). If the teaching of chemistry is not done with students actively engaged in class, the concept will not be embedded in the students' minds.

Alita \& Özer, 2017 state that the everyday use of teacher-centered teaching has attracted attention. The traditional approach orients to memorizing make the students accustomed to the prepared one negatively affect the sense of curiosity and causes raising individual who does not question. Morais et al (2017) which states that in the school context, the teachers are a source of information to students and act as role models for students. Therefore, to realize that the curriculum into an opportunity to develop creativity, teachers should use the opportunity to practice creative teaching practices in the classroom. Thus, it could enhance creative thinking among students. There is no previous research being conducted on creative teaching in chemistry. Therefore, it is essential to cultivate creative teaching among chemistry teachers to make a meaningful lesson for students.

Table 1: Summary on issues in chemistry Education

\begin{tabular}{ll}
\hline \hline \multicolumn{1}{c}{ Researchers } & \multicolumn{1}{c}{ Findings } \\
\hline \hline Gabel,1999 & Must create a meaningful Chemistry teaching \\
\hline Sirhan, 2007 & Chemistry difficult due to its abstract concept \\
\hline Treagust \& Chittleborough, 2001 & $\begin{array}{l}\text { Chemistry- macroscopic, microscopic, and } \\
\text { symbolic representation }\end{array}$ \\
\hline $\begin{array}{l}\text { Hofstein, Eilks, Bybee,2011; } \\
\text { Holbrook, Rannikmae, 2007; and } \\
\text { Osborne, J., \& Dillon, J. ,2008 }\end{array}$ & $\begin{array}{l}\text { Students are not motivated and irrelevant in their } \\
\text { perception to study chemistry. }\end{array}$ \\
\hline Dillon, 2009 and Gilbert, 2006 & $\begin{array}{l}\text { More hands-on are required to understand } \\
\text { particular theory and concepts of chemistry }\end{array}$ \\
\hline Hassan Touli et al.,2015 & $\begin{array}{l}\text { Explored different methods and teaching style in } \\
\text { chemistry class but did not explore creative } \\
\text { teaching in the chemistry classroom }\end{array}$ \\
\hline $\begin{array}{l}\text { Dogar et al., 2011; Gurses et al., 2007s } \\
\text { Ozmen \& Ayas, 2003 }\end{array}$ & $\begin{array}{l}\text { Actively engaged in the learning process with } \\
\text { better instruction and guidance required for a } \\
\text { better understanding of chemistry concepts. }\end{array}$ \\
\hline $\begin{array}{l}\text { Correiro, Griffin \& Hart, 2008; Martin } \\
\text { Hansen, 2005; Lindquist, 2001 }\end{array}$ & $\begin{array}{l}\text { The teachers-centered approach affects the } \\
\text { student's sense of curiosity of learning chemistry, } \\
\text { and they become passive }\end{array}$ \\
\hline Gurses et al.,2015 &
\end{tabular}

\section{Design Thinking Approach for Chemistry Education}

Design Thinking is a discipline that uses the designer's mindset and sensibility to satisfy the end-users needs, thereby converting into customer value and market opportunity (Barroca \& Soares, 2017). In short, design thinking uses the sensibilities or mindsets and methodologies often used by designers to create new ideas, solutions, alternatives, and choices that satisfy the desires of the end-users or stakeholders. Design thinking is launched by Stanford Design School (D.school) and the IDEO Design Consulting Company. The whole set of design thinking is comprised of five steps : (1) empathize; (2) define; (3) ideate; (4) prototype; and (5) test. 


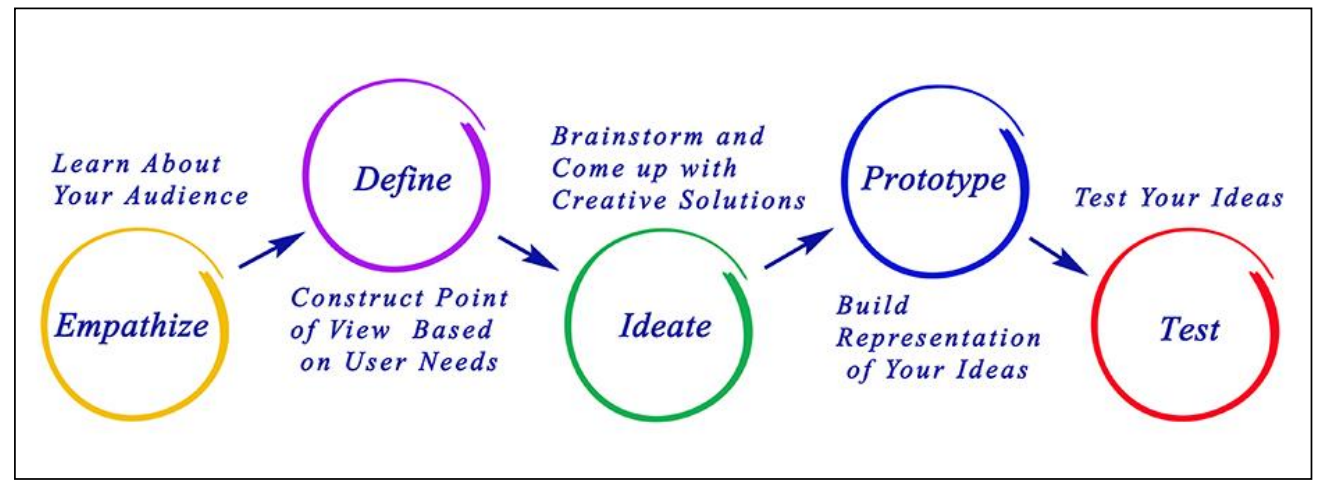

Figure 1: Design Thinking Process

(Source: Stanford Design School)

Design Thinking has advocated taking humans as the core of thinking and design. The method gets to know users and defines user demands through stages to trigger students' creativity and inspiration and motivate them to present creative ideas with a prototype quickly. Then, the ideas are improved through testing. Design thinking can realize the objective of getting to know user demands procedurally, and new design ideas can catch the design community's attention. Educators who have applied design thinking in education argued that it promotes innovation, problem-solving, creativity, and collaboration (Jobst et al., 2017; Anderson, 2012; Skaggs et al., 2009; Scheer et al., 2011; Watson, 2015; Caruso, 2011). Scheer and Plattner (2011) noted that design thinking effectively fosters 21st century learning through its application in complex interdisciplinary projects in a holistic constructivist manner. As a holistic concept to design cognition and Learning, design thinking allows the participants to work successfully in multidisciplinary teams to solve difficult real-life problems (Rauth et al. 2010).

\section{Recommendation In Chemistry Classroom}

\section{A) Development of Lesson Plan using Design Thinking Tool}

Teachers can use a design thinking approach to design their lessons. Teachers are, on the whole, incredibly empathetic. They know what their students are experiencing, and they feel it on a profound level. However, it is easy to get into a "program mindset," where you think about ideal systems and forget about students' experience. Design Thinking gains momentum as a mainstream framework in many countries today (Durall et al., 2020). The need to explicitly teach the components of this construct is gaining attention. Empathy, the beginning stage of the Design Thinking framework (Seidel, Victor \& Marion, Tucker \& Fixson, Sebastian, 2020), is arguably the most important as it provides a foundation for all future learning in a project or unit. Empathy is the critical notion required to tailor the need of students accordingly. This is a human-centered approach as an essential starting point for any lessons. In this mode, teachers observe students and their behaviors, interact with and interview them, and immerse themselves in understanding the students' experience and perspective. These insights allow teachers to approach the rest of the process with a more robust understanding of the context and problem. Besides that, they can loosen the narrow, rigid process of traditional Learning and tap into students' deep wells of creativity, encourage them to see slight problems from inside the core of an issue, and make creative thinking essential to solving any problem. 


\section{B) Project-Based Learning (PBL) using Design Thinking:}

Teachers always face a daunting task to bridge their requirements for today with their students' requirements for tomorrow. Project-Based Learning (PBL) and design thinking may provide teachers with two avenues to scaffold their thinking and instruction as they move toward innovating their classrooms. Project-Based Learning is an approach to teaching that requires students to engage in real-world problems, develop innovative solutions to those problems, and present their findings to their friends in the classroom or school. Design thinking can be used as a framework for implementing Project-Based Learning effectively in the classroom. The Design Thinking process scaffolds student thinking and provides essential structure to guide students through an innovative thinking process. The design thinking process adds a tight focus to a project; its straightforward step-by-step approach helps students manage their work and create high-quality products and solutions. Design thinking has added useful new tools and processes to the broader categories in education under which it and PBL fall: constructivism and inquiry learning. Design thinking focuses on real-world problems or needs. The process begins with understanding the real needs of students. The next steps include defining the task and roles, decisions needed, and challenges expected. Then comes idea generation, prototyping products/solutions, followed by testing to see if they work or need revision. Scaffolding teachers and schools with a flexible framework on lesson plans may help teachers implement PBL and Design Thinking within and across learning areas. Both build 21st-century success skills, feature authentic assessment, and require inquiry over time.

Table 2: Summary Of Design Thinking -Parallel To Project Based Learning.

\begin{tabular}{ll}
\hline \multicolumn{1}{c}{ Design Thinking } & \multicolumn{1}{c}{ Project-Based Learning } \\
\hline Empathy & $\begin{array}{l}\text { Entry event leads students to identify or become emotionally } \\
\text { engaged by an authentic problem or issue; they consider who } \\
\text { would benefit from the project or communicate directly with } \\
\text { someone to understand their needs. }\end{array}$ \\
\hline Define & $\begin{array}{l}\text { The project is framed by a driving question or challenge/problem } \\
\text { statement. Roles, teams, and tasks are planned. Need to know the } \\
\text { list is created. }\end{array}$ \\
\hline Ideate & $\begin{array}{l}\text { Students build knowledge and skills, then generate ideas for } \\
\text { products and possible answers for the question }\end{array}$ \\
\hline Prototype & $\begin{array}{l}\text { Students create rough drafts, models, drawings, plans and develop } \\
\text { answers for the question. }\end{array}$ \\
\hline Test & $\begin{array}{l}\text { Students make their work public and get feedback by engaging in } \\
\text { rounds of critique and revision. }\end{array}$ \\
\hline
\end{tabular}

Existing research has shown that design thinking can foster creativity and innovation, mostly when set in a collaborative multidisciplinary, interdisciplinary approach to problemsolving (Dogara et al., 2020). Carroll et al., 2010 proposed design thinking as an approach to learning that focuses on developing students' creative confidence through hands-on projects that focus on empathy, promoting a bias towards action, encouraging ideation, and fostering active problem-solving. It is noted that its power as a tool for Learning comes in the ways it can support a diverse range of interdisciplinary academic content. 


\section{Conclusion}

Chemistry teaching and learning in secondary schools in Malaysia have to become more responsive and creative. Educators are being asked to teach and develop curriculum in a manner far different from what they have been done and think creatively about their teaching and curriculum. This is difficult for chemistry teachers who rely on traditional modes of teaching, and it can be a struggle to teach differently. We have found that undertaking creative teaching promises the intrinsic reward of fulfillment. We have suggested that the Design thinking approach fosters creative teaching in the chemistry classroom.

As proposed in this study, the DT framework can be utilized as an important tool to foster creative teaching among chemistry teachers in designing creative lesson plans, which, when carefully implemented, can help students gain an efficacious, meaningful learning experience. The use of the DT framework can help chemistry teachers think and act creatively and innovatively to help them create effective and significant chemistry teaching activities. In other words, DT framework can mold them into better chemistry teachers that can teach chemistry subject to students creatively

\section{References}

Abrahams, I., \& Millar, R. (2008). Does Practical Work Really Work? A study of the effectiveness of practical work as a teaching and learning method in school science. International Journal of Science Education, 30(14), 1945-1969. doi:10.1080/09500690701749305

Ahmad, A. A., Ismail, F., Ibrahim, N. M., \& Samat, N. A. (2017). Investigating the Implementation of Higher Order Thinking Skills in Malaysian Classrooms: Insights from L2 Teaching Practices. Sains Humanika, 9(4-2). doi:10.11113/sh.v9n4-2.1361

Amabile, Teresa M. 2018. Creativity in Context: Update to the Social Psychology of Creativity. New York: Routledge.

Amir , N., Siew, \& Chong, C. L. (2015). The Perceptions of Preservice and In-service Teachers Regarding a Project-Based STEM Approach to Teaching Science. SpringerPlus, 4(1), 120.

Andrew. (2015). World Economic Forum Annual Meeting 2015. Retrieved https://www.weforum.org/events/world-economic-forum-annual-meeting-2015

Ali, M., Ibrahim, N. H., Abdullah, A. H., Surif, J., Talib, C. A., \& Saim, N. (2015). Web Pro-Mc Physics as a support tool for improving physics problem solving skills. 2015 Game Physics and Mechanics International Conference (GAMEPEC). doi:10.1109/gamepec.2015.7331851

Aliusta, G. O., \& Özer, B. (2017). Student-Centered Teacher Roles and Student-Centered Student Roles Teacher Interview. PsycTESTS Dataset. doi:10.1037/t62222-000

Amir, N. (2015). Showcasing the Creative Talents in Science of the Academically LessInclined Students through a Values-Driven Toy Storytelling Project. Cases on Instructional Technology in Gifted and Talented Education Advances in Early Childhood and K-12 Education, 141-179. doi:10.4018/978-1-4666-6489-0.ch007

Anderson, J. C., \& Naeim, F. (2012). Basic Structural Dynamics. doi:10.1002/9781118279137

Andrew. (2015) World Economic Forum Annual Meeting 2015 Retrieved July 01, 2019 from https://www.weforum.org/events/world-economic-forum-annual-meeting-2015 
Balaji, G. (2017). Learning Styles Among Secondary School Students. Scholarly Research Journal for Humanity Science \& English Language, 4(24). doi:10.21922/srjhsel.v4i24.10417

Barroca, A., \& Soares, J. (2017). Design Thinking Mindset Applied To Education And Training. INTED2017 Proceedings. doi:10.21125/inted.2017.1988

Bottia, M. C., Stearns, E., Mickelson, R. A., Moller, S., \& Valentino, L. (2015). Growing the roots of STEM majors: Female math and science high school faculty and the participation of students in STEM. Economics of Education Review, 45, 14-27. doi:10.1016/j.econedurev.2015.01.002

Burnard, P. (2016). Considering creative teaching in relation to creative Learning. Creative Teaching for Creative Learning in Higher Music Education, 49-62. doi:10.4324/9781315574714-5

Cardellini, L. (2012). Chemistry: Why the Subject is Difficult? Educación Química, 23, 305310. doi:10.1016/s0187-893x(17)30158-1

Carroll, M., Goldman, S., Britos, L., Koh, J., Royalty, A., \& Hornstein, M. (2010). Destination, Imagination and the Fires Within: Design Thinking in a Middle School Classroom. The Journal of Academic development and Education, 1.

Carroll, M. (2014). Learning from What Doesn't Work: The Power of Embracing a Prototyping Mindset. Retrieved from web.stanford.edu/group/redlab/cgibin/publications_resources.php

Caruso, C. (2011). The Tools of Engagement: Bridging Design Thinking and Social Media to Enhance and Support Collaborative Learning. Carleton University.

Correiro, E. E., Griffin, L. R., \& Hart, P. E. (2008). A constructivist approach to inquiry-based Learning: A TUNEL assay for the detection of apoptosis in cheek cells. American Biology Teacher, 70(8), 457-460. https://doi.org/10.1662/00027685(2008)70[457:ACATIL]2.0.CO;2

DeWitt, D., \& Alias, N. (2015). The principles of learning for problems solving. Proceedings in Seminar Kebangsaan Majlis Dekan-Dekan Pendidikan Universiti Awam. Batu Pahat, Johor, Malaysia: Universiti Tun Hussein Onn Malaysia.

Diaz, I. S., Goldhausen, I., Weise, L., Ralle, B., \& Fuccia, D. D. (2018). Magic In Chemistry Class: An Activity To Foster Students' Interest. INTED2018 Proceedings. doi:10.21125/inted.2018.1246

Dillon, J. (2009). On scientific literacy and curriculum reform. International Journal of Environmental \& Science Education, 4, 201-213.

Eilks, I., \& Hofstein, A. (2017). Curriculum Development in Science Education. Science Education, 169-181. doi:10.1007/978-94-6300-749-8_13

Elkind D: Dialogue on Early Childhood Science, Mathematics, and Technology Education. American Association for the Advancement of Science, Medford; 1999

Ellingson, L. L. (2018). Pedagogy of Laughter: Using Humor to Make Teaching and Learning More Fun and Effective. Teaching with Sociological Imagination in Higher and Further Education, 123-134. doi:10.1007/978-981-10-6725-9_8

Febriana, B., \& Arlianty, W. (2017). The Application Of Authentic Assessment In Chemistry Curriculum Studies. doi:10.17501/icedu.2017.3111

Fulmer, G. W. (2013). Constraints on Conceptual Change: How Elementary Teachers' Attitudes and Understanding of Conceptual Change Relate to Changes in Students' Conceptions. Journal of Science Teacher Education, 24(7), 1219-1236. doi:10.1007/s10972-013-9334-3 
Gilbert, J. K. (2006). On the nature of 'context' in chemical education. International Journal of Science Education, 28, 957-976

Grainger, T., Barnes, J., \& Scoffham, S. (2004) A creative cocktail Creative teaching in initial teacher education. Journal of Education for Teaching, 30, 243-253.

Gurses, A., Acikyildiz, M., Dogar, C., \& Sozbilir, M. (2007). An investigation into the effectiveness of problem-based Learning in a physical chemistry laboratory course. Research in Science \& Technological Education, 25, 99-113

Gürses, A., Çetinkaya, S., Doğar, Ç., \& Şahin, E. (2015). Determination of levels of use of basic process skills of high school students. Procedia - Social and Behavioral Sciences, $191,644-650$

Grainger, T., Barnes, J., \& Scoffham, S. (2004). A creative cocktail: Creative teaching in initial teacher education. Journal of Education for Teaching, 30(3), 243-253. doi:10.1080/0260747042000309475

Halim, L., \& Meerah, T. S. (2016). Science Education Research and Practice in Malaysia. Science Education Research and Practice in Asia, 71-93. doi:10.1007/978-981-10-0847-4_5

Hofstein, A., \& Kesner, M. (2006). Industrial Chemistry and School Chemistry: Making chemistry studies more relevant. International Journal of Science Education, 28(9), 1017-1039. doi:10.1080/09500690600702504

Halim, L., \& Meerah, S. M. T. (2016). Science education research and practice in Malaysia. In Science Education Research and Practice in Asia: Challenges and Opportunities (pp. 71-93). Springer Singapore. https://doi.org/10.1007/978-981-10-0847-4_5

Hofstein, A., Eilks, I., \& Bybee, R. (2011). Societal issues and their importance for contemporary science education: a pedagogical justification and the state of the art in Israel, Germany and the USA. International Journal of Science and Mathematics Education, 9, 1459-1483.

Holbrook, J., \& Rannikmäe, M. (2007). The nature of science education for enhancing scientific literacy. International Journal of Science Education, 29, 1347-1362

Idris, N. B. (2019). Malaysia. Issues in Upper Secondary Science Education. doi:10.1057/9781137275967.0010

Ingram, D. D., \& Ingram, D. (2020). Beautiful chemistry: Getting high school girls interested in chemistry. doi:10.1021/scimeetings.0c06149

Irwanto. (2018). Using Integrated Assessment To Measure Students' Analytical Thinking And Science Process Skills. doi:10.31227/osf.io/rjk6u

Jayarajah, K., Saat, R. M., Rauf, R. A. A. (2014). A Review of Science, Technology, Engineering \& Mathematics (STEM) Education Research from 1999-2013: A Malaysian Perspective. Eurasia Journal of Mathematics, Science and Technology Education, 10(3), 155-63. https://doi.org/10.12973/eurasia.2014.1072a

Jamil, S. Z., \& Khairuddin, R. F. (2017). Students interest in learning science through fieldwork activity encourage critical thinking and problem solving skills among UPSI pre-university students. doi:10.1063/1.4983913

Jobst, B., Köppen, E., Lindberg, T., Moritz, J., Rhinow, H., \& Meinel, C. (2012). The FaithFactor in Design Thinking: Creative Confidence Through Education at the Design Thinking Schools Potsdam and Stanford? Design Thinking Research, 35-46. doi:10.1007/978-3-642-31991-4_3

Johansson-Sköldberg, U., Woodilla, J., \& Çetinkaya, M. (2013). Design Thinking: Past,Present and Possible Futures. Creativity and Innovation Management, 22(2), 121-146. 
Kidman, G., \& Casinader, N. (2017). Inquiry-Based Teaching and Learning across Disciplines. doi:10.1057/978-1-137-53463-7

Kim, K. H., Williams, N., \& Siradakis, A. (2019). Rural Creativity and Urban Creativity. Encyclopedia of Creativity, Invention, Innovation and Entrepreneurship, 1-4. doi:10.1007/978-1-4614-6616-1_200068-1

Kwek, D. (2011). Innovation in the Classroom: Design Thinking for 21st Century Learning.Stanford EDU,(2011). Retrieved from http://www.stanford.edu/group/redlab/cgi-bin/materials/Kwek-Innovation In The Classroom.pdf

Lindquist, W. P. (2001). A case study of online collaborative inquiry in an elementary classroom. PhD Thesis, University of Minnesota.

Lee, C. D. (2019). Practice that supports learning and development: A commentary. Applied Developmental Science, 24(2), 141-145. doi:10.1080/10888691.2019.1609735

$\mathrm{Li}, \mathrm{Y}$. (2014). International Journal of STEM Education - a platform to promote STEM education and research worldwide. International Journal of STEM Education, 1(1). doi:10.1186/2196-7822-1-1

Malaysia Education Blueprint 2013-2025 (2012). Preliminary Report: Malaysia Education Blueprint 2013-2025. [online] moe.gov.my. Available at: http://www.moe.gov.my/userfiles/file/PPP/Preliminary-Blueprint-Eng.pdf .

Martin-Hansen, L. M. (2005). Crayfish investigations: Inquiry in action for grades 4-8. Science Activities, 41 (4), 3-6.

Martin, M. O., Mullis, I. V. S., Foy, P., \&Stanco, G. M. (2012).TIMSS 2011 International results in science. Chestnut Hill, MA: TIMSS \& PIRLS International Study Center, Boston College

Meyer, D. (2012) : Designing design challenges - getting the details right: using engineering problems to enact inquiry learning.Sci Teach 2012,79(2):58-62.

Meinel, C., \& Leifer, L. (2011). Design Thinking Research. Design Thinking Research, 1-11. doi:10.1007/978-3-642-21643-5_1

Ministry of Education, MOE. (2013). Malaysia Education Blueprint Executive Summary [Online], Available: http://www.moe.gov.my/cms/upload_files/articlefile/2013/ articlefile_file_003114.pdf [28 Aug 2014]

Ministry of Education, MOE (2014). Malaysia Education Blueprint annual report [Online], Available: http://www.padu.edu.my/files/AR/PADU_AR_2013_ENG.pdf [01 Sep 2014]

Ministry of Science, Technology and Innovation (MOSTI). (2017). Science and Technology Human Capital Roadmap: Towards 2020. Putrajaya: Malaysian Science and Technology Information Centre, MOSTI

Mohandas, P., \& Rajaratnam, P. OC. (2015). A policy analysis of the delivery of primary and secondary school Mathematics and Science in English. Education Research and Perspectives, 4(2015), 246-285

Morais, M. F., \& Azevedo, I. (2010). What is a creative teacher and what is a creative pupil? Perceptions of teachers. Procedia Social and Behavioral Sciences, 12, 330-339.

Muhlisin, A. (2017). An Analysis of University Students' Conceptual Understanding and Retention on Science Basic Concepts. doi:10.31227/osf.io/yztdx

Nieswandt, M., \& Horowitz, G. (2015). Undergraduate Students' Interest in Chemistry: The Roles of Task and Choice. Interest in Mathematics and Science Learning, 225-242. doi:10.3102/978-0-935302-42-4_13 ). Undergraduate Students' Interest in Chemistry: The Roles of Task and Choice. Interest in Mathematics and Science Learning, 225-242. doi:10.3102/978-0-935302-42-4_13 
Niaz, M., \& Luiggi, M. (2014). Facilitating Conceptual Change in Students' Understanding of the Periodic Table. SpringerBriefs in Education. doi:10.1007/978-3-319-01086-1

Odell, M., \& Kennedy, T. J. (2020). Inquiry-Based Pedagogy To Support Stem Learning And 21St Century Skills: Preparing New Teachers To Implement Project And Problem-Based Learning. INTED2020 Proceedings. doi:10.21125/inted.2020.1976

OECD. (2017), education at a Glanc 2017: OECD Indicators, OECD Publishing, Paris .http://dx.doi.org/10.1787/eag-2017-enOsborne, J., \& Dillon, J. (2008). Science education in Europe: critical reflections. London: The Nuffield Foundation

Otte, C. R., Bølling, M., Elsborg, P., Nielsen, G., \& Bentsen, P. (2019). Teaching maths outside the classroom: Does it make a difference? Educational Research, 61(1), 38-52. doi:10.1080/00131881.2019.1567270

Park, G., Lubinski, D., \& Benbow, C.P. (2007). Contrasting intellectual patterns predict creativity in the arts and in the sciences: Tracking intellectually precocious youth over 25 years. Psychological Science, 18: 948-952

Plattner, H., Meinel, C., \& Leifer, L. (2011). Design Thinking: Understand-Improve-Apply.Berlin: Springer-Verlag. http://doi.org/10.1007/978-3-642-13757-0

Purdy, J. P. (2014). What can design thinking offer writing studies? College Composition and Communication, 65(4), 612-641.

Rahmawati, M. A., Agustin, A., Ridwan, E., Erdawati, D., Darwis, R., \& Rafiuddin. (2019) The development of chemistry students' 21 century skills through a STEAM project on electrolyte and non-electrolyte solutions. Journal of Physics: Conference Series 1402, 055049.

Rauth, I., Köppen, E., Jobst, B., \& Meinel, C. (2010). Design Thinking: An Educational Model towards Creative Confidence. In First International Conference on Design Creativity (pp.1-8). Kobe, Japan.

Regan, E., \& DeWitt, J. (2015). Attitudes, interest and factors influencing STEM enrolment behaviour: An overview of relevant literature. In Understanding student participation and choice in science and technology education (pp. 63-88). Springer Netherlands.

Rotherham, A. J., \& Willingham, D. (2009). 21st century. Educational leadership, 67(1), 16-21.

Sadler, P. M., Sonnert, G., Coyle, H. P., Cook-Smith, N. ,and Miller, J. L. (2013). The influence of teachers' knowledge on student learning in middle school physical science classrooms, American Educational Research Journal, 50(5): 1020-1049

Sadler, P. M., Sonnert, G., Coyle, H. P., Cook-Smith, N. and Miller, J. L. (2013). The influence of teachers' knowledge on student learning in middle school physical science classrooms, American Educational Research Journal, 50(5), 1020-1049

Sadler, P. M., Sonnert, G., Coyle, H. P., Cook-Smith, N. and Miller, J. L. (2013). The influence of teachers' knowledge on student learning in middle school physical science classrooms, American Educational Research Journal, 50(5), 1020-1049

Regan, E., \& Dewitt, J. (2014). Attitudes, Interest and Factors Influencing STEM Enrolment Behaviour: An Overview of Relevant Literature. Understanding Student Participation and Choice in Science and Technology Education, 63-88. doi:10.1007/978-94-0077793-4_5

Russell, J. W., Kozma, R. B., Jones, T., Wykoff, J., Marx, N., \& Davis, J. (1997). Use of Simultaneous-Synchronized Macroscopic, Microscopic, and Symbolic Representations To Enhance the Teaching and Learning of Chemical Concepts. Journal of Chemical Education, 74(3), 330. doi:10.1021/ed074p330 
Sadler, P. M., Sonnert, G., Coyle, H. P., Cook-Smith, N. and Miller, J. L. (2013). The influence of teachers' knowledge on student learning in middle school physical science classrooms.American Educational Research Journal, 50(5): 1020-1049

Sadler, M. (2013). 2020 Vision. Itnow, 55(1), 22-23. doi:10.1093/itnow/bws134

Silverman, M. P. (2015). Motivating Students to Learn Science: A Physicist's Perspective. Creative Education, 06(18), 1892-1992. doi:10.4236/ce.2015.618203

Scheer, A., \& Plattner, H. (2011). Transforming Constructivist Learning into Action: Design Thinking in education. Design and Technology Education: An International Journal, 17(3), 8-19.

Sirhan, G. (2007). Learning difficulties in chemistry An overview. Journal of Turkish Science Education, 4, 2-20.

Scoffham, Stephen and Barnes, Jonathan (2011). Happiness Matters: Towards a Pedagogy of Happiness and Well-being. The Curriculum Journal, 22(4), pp. 535-548

Skaggs, P., Fry, R., \& Howell, B. (2009). Innovations Unlimited: Thinking About Design Thinking. In The NCIIA 13th Annual Meeting (p. 2009). Washington, D.C.

Starko, A. J. (2013). creativity in the classroom: Schools of curious delight. Routledge.

Starko, A. J. (2013). Creativity in the Classroom. doi:10.4324/9780203115176

Steele, D., \& Whitaker, T. (2019). Good Lesson Plans Don't Redeem Poor Relationships. Get to Know Your Students ... Then It Becomes Much Easier to Teach Them. Essential Truths for Teachers, 11-12. doi:10.4324/9780429022029-7

Starko, A. J., \& Krynski, A. (2020). Classroom Environment Conducive to Creativity. Encyclopedia of Educational Innovation, 1-6. doi:10.1007/978-981-13-2262-4.

Sindia, S. (2015). Innovative practices session 2C: New technologies, new challenges - 2. 2015 IEEE 33rd VLSI Test Symposium (VTS). doi:10.1109/vts.2015.7116258

Touli, E., Talbi, M., \& Radid, M. (2015, June 18). Teaching and Learning of Experimental Science: The Case of Chemistry in Secondary Qualifying Morocco.

Thomas, S., \& Budnik, M. (2017). Can a First-year Professor be More Successful with a Flipped Classroom than with a Traditional Classroom? 2017 ASEE Annual Conference \& Exposition Proceedings. doi:10.18260/1-2-28001

Treagust, D. F., \& Duit, R. (2008). Conceptual change: A discussion of theoretical, methodological, and practical challenges for science education. Cultural Studies of Science Education, 3(2), 297-328.

Watson, A. D. (2015). Design Thinking for Life. Art Education, 68(3), 12-18. Retrieved fromhttp://search.ebscohost.com/login.aspx?direct=true \&db=eric\&AN=EJ106038 2\&lang=de\&site=edslive\&authtype=ip,uid \nhttp://www.arteducators.org/research/ art-education

Westwood, P. (2013). Inclusive and Adaptive Teaching: Meeting the challenge of diversity in the classroom (1st ed.). Routledge. https://doi.org/10.4324/9780203069806

World Economic Forum. (20160. The Global Competitiveness Report 2015-2016. Geneva : World Economic Forum.

World Economic Forum. (2018). The Future of Jobs Report 2018,Geneva: World Economic Forum: ISBN 978-1-944835-18-7

Widodo, S. (2018). Implementation Of Tgt Learning Model To Improve Learning Activities And Study Results. JCER (Journal of Chemistry Education Research), 2(1), 37. doi:10.26740/jcer.v2n1.p37-44 
INTERNATIONAL JOURNAL OF ACADEMIC RESEARCH IN BUSINESS AND SOCIAL SCIENCES

Vol. 11, No. 3, 2021, E-ISSN: 2222-6990 @ 2021 HRMARS

Yaman, F., Ayas, A., \& Çalik, M. (2019). Facilitating grade 11 students' conceptual understanding of fundamental acid-base models. Turkish Journal of Education, 16-32. doi:10.19128/turje.449100 